\title{
In vitro inhibition of human leukemia THP-1 cells by Origanum syriacum L. and Thymus vulgaris L. extracts
}

\author{
Basim M Ayesh' ${ }^{1}$, Abdalla A Abed² and Doa'a M Faris ${ }^{3 *}$
}

\begin{abstract}
Background: Natural products including, traditional medicinal plants have emerged as a tempting alternative to conventional chemotherapeutic protocols of leukemia because of their minimum side effects and less documented drug resistance.

Methods: Ethanol extracts were prepared from Thymus vulgaris L. and Origanum syriacum L. plants and investigated against the THP-1 leukemia cell line and freshly isolated peripheral blood mononuclear cells (PBMCs). The 3-[4,5-dimethylthiazol-2-yl]-2,5-diphenyl tetrazolium bromide (MTT) assay and the lactate dehydrogenase $(\mathrm{LDH})$ assay were respectively used to determine the cellular viability and cytotoxicity in response to treatment with increasing extract concentrations.

Results: Both extracts exhibited a concentration dependent reduction in viability of the THP-1 cells $\left(\mathrm{IC}_{50}=2.126 \mathrm{mg} / \mathrm{mL}\right.$ for 0 . syriacum, and $0.1569 \mathrm{mg} / \mathrm{mL}$ for $T$. vulgaris). O. syriacum was more potent against the PBMCs $\left(I C_{50}=0.4247 \mathrm{mg} / \mathrm{mL}\right)$, while $T$. vulgaris was moderately selective $\left(I_{50}=0.3345 \mathrm{mg} / \mathrm{mL}\right.$ with PBMCs and $\left.\mathrm{SI}=2.1\right)$. Only in 0 . syriacum the reduction in cells viability was caused by cytotoxic effect against leukemic cells ( $L C_{50}=$ of $\left.9.646 \mathrm{mg} / \mathrm{mL}\right)$.

Conclusion: T. vulgaris and O. syriacum are both antileukemic in vitro. T. vulgaris represents a potential selective cytostatic and safe target for future anticancer agents' development. O. syriacum on the other hand is cytotoxic against the leukemia cell line THP-1.
\end{abstract}

Keywords: Leukemia, THP-1 Cells, Origanum syriacum, Thymus vulgaris, Antiproliferative, Cytotoxic

\section{Background}

Depending on its type, leukemia may be successfully treated with chemotherapy, radiation therapy, hormonal therapy, or bone marrow transplantation. However, chemotherapeutic agents are highly toxic to a wide range of normal body cells, and thus are associated with diverse side effects. In addition, multiple drug resistance is a major determinant of chemotherapy failure. Therefore, natural products including, traditional medicinal plants, have emerged as a tempting more tolerated alternative with minimum side effects.

The leaves of Origanum syriacum L. (Syrian Oregano), which belongs to the Lamiaceae family and inhabits a large area in the eastern Mediterranean, have been

\footnotetext{
* Correspondence: d_fariss@yahoo.com

${ }^{3}$ European Gaza Hospital Laboratory, Ministry of Health, Gaza, Palestine

Full list of author information is available at the end of the article
}

widely used in the traditional herbal medicine $[1,2]$. Its composition and effects as antioxidant and antibacterial were extensively studied, but few were concerned with the antiproliferative and anticancer activities of this plant $[3,4]$.

Thymus vulgaris $\mathrm{L}$. (thyme) is a member of the genus Thymus (Lamiaceae family) which is predominantly found in the Mediterranean region, Asia, Southern Europe and North Africa [5]. Extracts of T. vulgaris are traditionally used as anti-asthmatic, bronchodilator, antitussive, antispasmodic [6], antibacterial, and antifungal $[7,8]$. In addition, these extracts have shown immunomodulating properties $[9,10]$. Different studies proposed that extracts of Thymus vulgaris may have potential anticancer effects [11-15].

In this study, we investigated the antiproliferative and cytotoxic effects of extracts from Origanum syriacum 
and Thymus vulgaris on the acute monocytic leukemia cell line THP-1 and human peripheral blood mononuclear cells (PBMCs) isolated from normal controls.

\section{Materials}

All cell culture reagents, media and supplements as well as cell viability kits and syringe filters were purchased from Sigma Aldrich (Israel). The THP-1 cell line was purchased from the European Collection of Cell Cultures (ECACC, UK). Cell culture flasks, well plates and other tissue culture plastics were purchased from Greiner Bio-One (Germany).

\section{Methods}

Collection of plant materials and preparation of extracts T. vulgaris seeds were purchased from PlantiCo (Poland) and implanted for six months. O. syriacum were obtained from Al-Breem plantation (Khanyounus) and authenticated by Dr. Mohammad Abo-Oda (PhD plant taxonomy, Alaqsa University, Gaza). Aerial parts were collected, washed, air-dried under shade for 3 weeks, and then completely dried by oven at $40^{\circ} \mathrm{C}$ for 1 to 1.5 hour.

Both plant extracts were prepared by soaking the dried and grinded aerial parts in ethanol at room temperature with occasional mixing (7 days, $40 \%$ ethanol for $O$. syriacum; and 4 days, $90 \%$ ethanol for T. vulgaris) in a weight/solvent volume ratio of $1 / 10$. Different ethanol concentrations were used according to the solubility preferences of the literature detailed effective compounds of each plant. The extracts were filtered under vacuum for three times, and dried by rotary evaporator at $40^{\circ} \mathrm{C}$ for $T$. vulgaris and $45^{\circ} \mathrm{C}$ for $O$. syriacum.

O. syriacum stock solution was finally prepared at a concentration of $200 \mathrm{mg}$ of the dry extract/mL of RPMI-1640 medium with $10 \%$ fetal bovine serum (FBS). T. vulgaris stock solution was prepared at the same concentration in dimethyl sulfoxide (DMSO). DMSO was used because $T$. vulgaris dry extract contains high percentage of oils and does not dissolve in the aqueous RPMI-1640 medium. The stock solutions were stored at $-20^{\circ} \mathrm{C}$ until used.

\section{Cell line culturing and maintenance}

The THP-1 cell line was derived from the peripheral blood of a 1 year old male with acute monocytic leukemia. The cells were cultured in modified RPMI-1640 complete medium with $2.05 \mathrm{mM}$ L-glutamine and $25 \mathrm{mM}$ HEPES, supplemented with $10 \%$ heat inactivated $\mathrm{FBS}$ at $37^{\circ} \mathrm{C}$ in a humidified atmosphere with $5 \% \mathrm{CO}_{2}$. Cell counts and viability estimation by trypan blue dye exclusion test were performed regularly. Throughout the study procedures, THP-1 cells were maintained in a logarithmic growth phase at a concentration between $10^{5}-10^{6}$ cells $/ \mathrm{mL}$. Media feeding was performed periodically every $2-4$ days.

\section{Isolation of human Peripheral Blood Mononuclear Cells (PBMCs)}

PBMCs were isolated from sodium heparin anticoagulated venous blood of healthy donors using Sigma's Histopaque1077 as recommended. The donors' consents were obtained before sample collection, and the procedure was approved by the local Helsinki committee of the Palestinian Health Research Council, according to the World Medical Association Declaration of Helsinki (approval reference No. 1-12/2012). The cells were suspended at a concentration of $10^{6}$ cells $/ \mathrm{mL}$ in modified RPMI-1640 medium, with $2.05 \mathrm{mM}$ L-glutamine and $25 \mathrm{mM}$ HEPES, supplemented with 10\% FBS, $5 \mu \mathrm{g} / \mathrm{mL}$ phytohemagglutinin (PHA), $100 \mu \mathrm{g} / \mathrm{mL}$ streptomycin, and $100 \mathrm{U} / \mathrm{mL}$ penicillin.

\section{Cells preparation and extracts treatment}

THP-1 cells in the exponential growth phase and viability of at least $95 \%$ and freshly isolated PBMCs with viability of at least $98 \%$ were used for the viability assays. The cells were seeded in 96-well plates at a density of $10^{4}$ THP-1 cells/well and $10^{5}$ PBMCs cells/well in $100 \mu \mathrm{L}$ of the culture medium. Another $100 \mu \mathrm{L}$ of the proper extract working concentration were added to the corresponding wells in triplicates, and the cells were incubated for $48 \pm 1$ hours in a humidified $\mathrm{CO}_{2}$ incubator at $37^{\circ} \mathrm{C}$ and $5 \% \mathrm{CO}_{2}$.

The various extract working concentrations were prepared by dilution of the stock solutions in culture medium and filter-sterilization with $0.22 \mu \mathrm{m}$ Millex-GP syringe filters. Corresponding DMSO concentrations were similarly prepared as vehicle controls for $T$. vulgaris extract.

\section{Cell viability assay}

The THP-1 cells and PBMCs previously incubated with the proper extract or DMSO concentration were washed several times with $150 \mu \mathrm{L}$ phosphate buffered saline (PBS) $(\mathrm{pH}=7.2-7.6)$ and plate-centrifugation, to remove any residual extract color that may interfere with the colorimetric assay. The extract-free cells were finally suspended in $100 \mu \mathrm{L}$ media with $10 \%$ heat inactivated FBS, and assayed for viability using the colorimetric MTT based in vitro toxicology assay kit following the manufacturer instructions. The assay measures the amount of the blue-colored formazan accumulated intracellularly following cleavage of the 3-(4,5-dimethylthiazol-2-yl)2,5-diphenyltetrazolium bromide (MTT) reagent by mitochondrial dehydrogenases of the viable cells. The absorbance of the produced intracellular formazan which is proportional to the number of viable cells present was determined at $550 \mathrm{~nm}$. Absorbance for background correction was determined at $620 \mathrm{~nm}$. Absorbance of wells filled with media alone was used as a blank and untreated control 
wells were seeded with cells that incubated without any extracts. The percentage of cell survival was calculated after background absorbance correction and blank absorbance subtraction as follows: \% Cell viability $=100 \mathrm{X}$ Experimental well absorbance / untreated control well absorbance.

\section{Cytotoxicity assay}

The THP-1 cells were treated with various extracts or DMSO concentrations. Cells in the positive control wells were treated with $1 \%$ Triton X-100 solution, and negative control wells cells were incubated in culture media alone. Blank wells contained the corresponding extract concentrations or Triton X-100 solution or media without cells. The lactate dehydrogenase (LDH) based in vitro toxicology assay kit was used to assay for cytotoxicity following the manufacturer instructions. The assay measures membrane integrity as a function of the amount of cytoplasmic LDH released into the medium. $\mathrm{LDH}$ reduces NAD into NADH, which is utilized in the reduction of a tetrazolium dye to colored formazan. The amount of formazan which is proportional to the amount of LDH release from dead cells was measured colorimetrically at $450 \mathrm{~nm}$. Absorbance for background correction was determined at $620 \mathrm{~nm}$.

The percentage of cell viability was calculated as follows: \% Cell viability $=100-\%$ cell cytotoxicity. The \% cell cytotoxicity $=100 \mathrm{X}$ (experimental well absorbance negative control well absorbance) / (positive control well absorbance -negative control well absorbance). All calculations were performed after background absorbance correction and blank absorbance subtraction.

\section{Statistical analysis}

All experiments were performed in triplicates and each experiment was performed for two times. The results were expressed as a mean viability percentage \pm standard deviation (SD). Dose response curves were prepared with Microsoft Office Excel 2007 software.

The data were analyzed using the GraphPad Prism software (Version. 6). The log (inhibitor) vs. response curve equation was used to determine the best fit and to
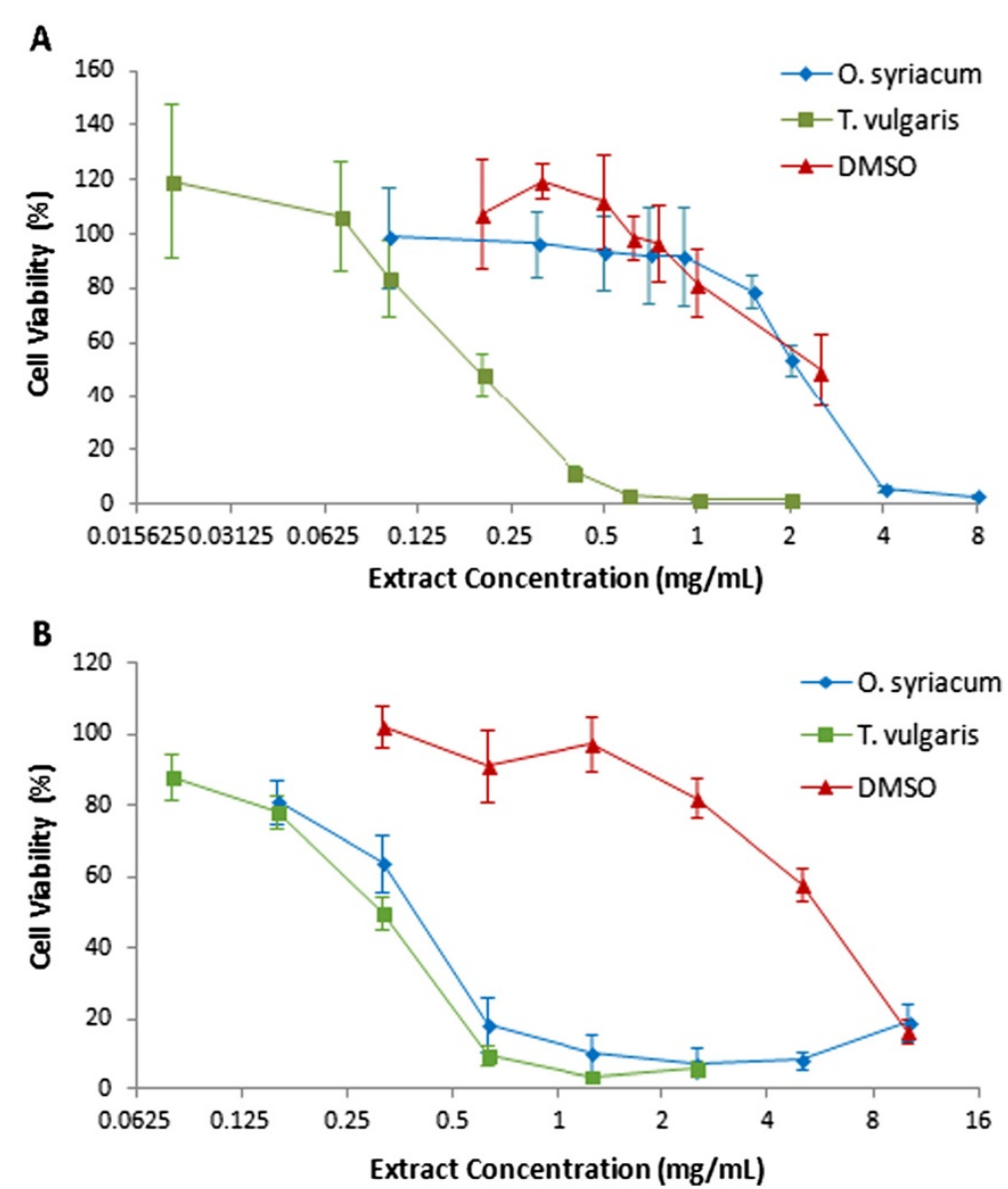

Figure 1 Reduction of THP-1 cells and PBMCs viability in response to increasing extracts and DMSO concentrations. Dose response curves of THP-1 cells (A) and PBMCs (B) were constructed after $48 \mathrm{~h}$ treatment with 0 . syriacum and T. vulgaris extracts and DMSO. The cells viability was assayed by the colorimetric MTT based assay. The X-axis is in logarithmic scale. 
Table $1 \mathrm{IC}_{50}$ values and selectivity indices ( $\mathrm{SI}$ ) of O. syriacum and T. vulgaris extracts

\begin{tabular}{ccccc}
\hline \multirow{2}{*}{$\begin{array}{c}\text { Plant } \\
\text { extract }\end{array}$} & \multicolumn{2}{c}{$\begin{array}{c}\mathrm{IC}_{\mathbf{5 0}}(\mathbf{9 5 \%} \text { Confidence } \\
\text { interval) in } \mathbf{~ m g} / \mathbf{m L}\end{array}$} & P-value & SI \\
\cline { 2 - 3 } & THP-1 Cells & PBMCs & & \\
\hline O. syriacum & $2.126(1.934-2.339)$ & $0.425(0.339-0.533)$ & $<0.0001$ & 0.2 \\
T. vulgaris & $0.157(0.133-0.186)$ & $0.334(0.311-0.359)$ & $<0.0001$ & 2.1 \\
\hline
\end{tabular}

All values were determined by GraphPad Prism nonlinear regression analysis. The Log (inhibitor) vs. response - Variable slope (four parameters) equation was used for best fit of all extracts curves. In all of these curves, the bottom was constrained to zero value. $\mathrm{SI}=\mathrm{IC}_{50}$ of extract in the normal cell line/IC $\mathrm{C}_{50}$ of the same extract in cancer cell line.

determine the $\mathrm{IC}_{50}$ and $\mathrm{LC}_{50}$ values, the concentration that provokes a response half way between the maximal and the maximally inhibited cell viability. The obtained curves on leukemic and normal cells for each extract were compared with respect to their $\mathrm{IC}_{50} / \mathrm{LC}_{50}$ and slope and the P-value was determined with $95 \%$ confidence intervals. Two-regression curves comparison was performed by the F-test and a significant difference was obtained at $\mathrm{P}$-values $<0.05$.

\section{Results}

Effects of the extracts on THP-1 Cells and PBMCs viability Both extracts $O$. syriacum, and T. vulgaris significantly reduced the number of viable THP-1 cells and PBMCs in a concentration dependent manner [Figure 1]. No effect was obtained with DMSO at the effective T. vulgaris extract concentrations. T. vulgaris extract effect was selective against leukemic cells with selectivity index (SI) of 2.1. An SI value $<2$ indicates a general nonspecific toxicity. On the other hand, the O. syriacum extract effect was more potent on normal cells than on leukemic cells.
The $\mathrm{IC}_{50}$ values for THP-1 cells and PBMCs as well as selectivity indices are listed in Table 1.

\section{Cytotoxic effects of the extracts on THP-1 cells}

The LDH assay was used in order to determine if the reduction in cell viability obtained with MTT assay was due to cytotoxicity or to an antiproliferative effect. T. vulgaris extract has not shown any cytotoxic effect against THP-1 leukemic cells compared to DMSO $(P$-value $=0.6520)$ [Figure 2]. O. syriacum extract on the other hand has shown significant cytotoxic effect against THP-1 cells with $\mathrm{LC}_{50}$ value of $9.646 \mathrm{mg} / \mathrm{mL}$.

\section{Discussion}

In this study, T. vulgaris exhibited a selective dose dependent inhibition of THP-1 proliferation (cytostatic activity) at the applied concentrations and exposure time rather than killing them (cytotoxic activity). These promising findings give hope that $T$. vulgaris may contain cancer therapeutic agents that, once purified, are more selective to leukemic cells than normal blood cells at relatively low concentrations. Furthermore, T. vulgaris is among the safest extracts used in herbal medicine, exhibiting only minor adverse effects [16].

Our results are consistent with other studies which demonstrated a dose dependent proliferation inhibition of human cancer cell lines from breast cancer, leukemia, cervical epithelial carcinoma, oral cavity squamous cell carcinoma, lung carcinoma and prostate carcinoma $[11,13,14,17]$. T. vulgaris essential oil were previously shown to interfere with the transcription of genes involved in the cell cycle, cell death and cancer, namely, interferon signaling, $\mathrm{N}$-glycan biosynthesis and extracellular signal-regulated kinase 5 (ERK5) signaling [13].

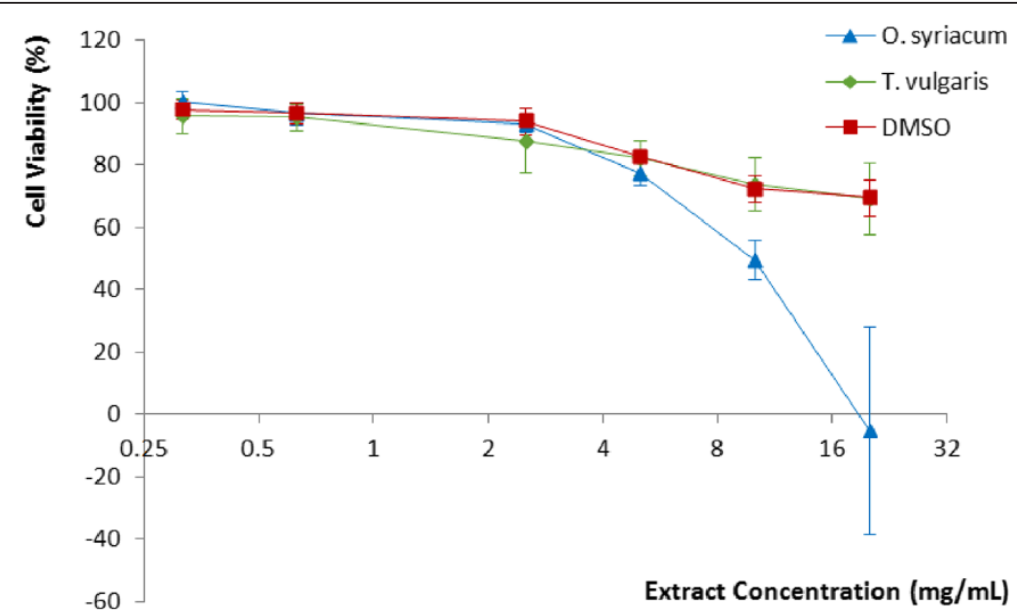

Figure 2 Cytotoxic effect on THP-1 cells in response to increasing extracts and DMSO concentrations. Dose response curves of THP-1 cells were constructed after $48 \mathrm{~h}$ treatment with $\mathrm{O}$. syriacum and T. vulgaris extracts and DMSO. Cytotoxicity was determined by LDH based assay. The $X$-axis is in logarithmic scale. 
In this study, $O$. syriacum extract has resulted in both reduced viability and increased cytotoxicity of the THP-1 and PBMCs. This would have been a much more valuable finding if the effect of $O$. syriacum extract was selective against the leukemic cells.

To the best of our knowledge, no previous studies have assessed the effect of O. syriacum against leukemia, although few ones reported an antiproliferative effect of $O$. syriacum crude extract against cancer cell lines derived from breast adenocarcinoma and human cervical adenocarcinoma $[3,4]$.

The effects imposed by the plant extracts on the normal PBMCs may have been aided by the challenges they face in culture, particularly when the culture media composition is modified by many substances present in the crude extracts. Such challenges are expected to affect normal cells more than leukemic cancer cells, which have gained some growth advantages during their multistage progress toward cancer. In this regard, T. vulgaris was shown by others to be inhibitory on normal Vero cell line and PBMCs at high concentrations [12,17]. Only one study was found in the literature to deal with O. syriacum cytotoxicity against the, supposed, normal diploid human embryonic fibroblasts MRC-5 cell line [18]. Like our results, the study showed that methanolic extracts of O. syriacum were cytotoxic against the MRC-5 cells with $\mathrm{IC}_{50}>64 \mu \mathrm{g} / \mathrm{mL}$. No other studies were found in the literature to investigate the cytotoxicity of the $O$. syriacum extracts against PBMCs.

T. vulgaris and O. syriacum essential oils cytotoxicity was investigated by others in vivo in Wistar rats, and no significant variations of hematological or biochemical parameters were noticed after the oral treatment with these essential oils compared to the control group treated with physiological solution [19].

\section{Conclusion}

In conclusion, $T$. vulgaris and O. syriacum are both antileukemic in vitro. T. vulgaris represents a potential selective cytostatic and safe target for future anticancer agents' development. O. syriacum, on the other hand, is cytotoxic against the leukemia cell line THP-1. Further in vitro and in vivo research has to be performed on the molecular mechanisms of their action as well as on the chemical identity of their active substances.

\section{Competing interests}

The authors declare that they have no competing interests.

\section{Authors' contributions}

BMA participated in the design of the study; supervised on the theoretical and practical research and the statistical analysis and drafted the manuscript. AAA supervised on the theoretical and practical work. DMF designed, carried out, and partially financed the laboratory procedures and the statistical analysis and helped in drafting the manuscript. All authors read and approved the final manuscript.

\section{Acknowledgement}

This study was performed in the Islamic University of Gaza laboratories with partial financial support by the Scientific Research Affairs of the University.

\section{Author details}

${ }^{1}$ Medical Technology Department, Faculty of Science, Alaqsa University, Gaza, Palestine. ${ }^{2}$ Biology and Biotechnology Department, Faculty of Science, the Islamic University of Gaza, Gaza, PalestineP.O.Box 108. ${ }^{3}$ European Gaza Hospital Laboratory, Ministry of Health, Gaza, Palestine.

Received: 2 March 2014 Accepted: 5 September 2014

Published: 7 September 2014

\section{References}

1. Alma M, Mavi A, Yildirim A, Digrak M, Hirata T: Screening of chemical composition and in vitro antioxidant and antimicrobial activities of the essential oils from Origanum syriacum L. growing in Turkey. Biol Pharm Bull 2003, 26:1725-1729.

2. letswaart J: A Taxonomic Re Vision of the Genus Origanum (Labiatae). The Netherlands: Leiden University Press; 1980

3. Al-Kalaldeh J, Abu-Dahab R, Afifi F: Volatile oil composition and antiproliferative activity of Laurus nobilis, Origanum syriacum, Origanum vulgare, and Salvia triloba against human breast adenocarcinoma cells. Nutr Res 2010, 30:271-278.

4. El-Desouky S, Ibrahima L, Kawashtya S, El-Ansari M, Kim YS, Chong HS, Kim OK, Kim YK: Phytochemical constituents and biological activities of Origanum syriacum. Z Naturforsch B 2009, 64:447-451.

5. Maksimovic Z, Stojanovic D, Sostaric I, Dajic Z, Ristic M: Composition and radical-scavenging activity of Thymus glabrescens Willd. (Lamiaceae) essential oil. J Sci Food Agric 2008, 88:2036-2041.

6. Meister A, Bernhard G, Chrisoffel V, Buschauer A: Antispasmodic activity of Thymus vulgaris extract on isolated guinea-pig trachea: discrimination between drug and ethanol effects. Planta Med 1999, 65:512-516.

7. Marino M, Bersani C, Comi G: Antimicrobial activity of the essential oils of Thymus vulgaris L. measured using a bioimpedometric method. J Food Prot 1999, 62:1017-1023.

8. Pina-Vaz C: Gonçalves Rodrigues C, Pinto E, Costa-de-Oliveira S, Tavares C, Salgueiro L, Cavaleiro C, Goncalves MJ, Martinez-de Oliveira J: Antifungal activity of Thymus oils and their major compounds. J Eur Acad Dermatol Venereol 2004, 18:73-78.

9. Bukovska A, Cikos S, Juhas S, Il'kova G, Rehak P, Koppel J: Effects of a combination of thyme and oregano essential oils on TNBS-induced colitis in mice. Mediators Inflamm 2007, 2007:1-9.

10. Ocaña A, Reglero G: Effects of thyme extract oils (from Thymus vulgaris, Thymus zygis, and Thymus hyemalis) on cytokine production and gene expression of oxLDL-stimulated THP-1- Macrophages. J Obes 2012, 2012:1-11.

11. Berdowska I, Zieliński B, Fecka I, Kulbacka J, Saczko J, Gamian A: Cytotoxic impact of phenolics from Lamiaceae species on human breast cancer cells. Food Chem 2013, 15:1313-1321.

12. Berrington $D$, Lall $N$ : Anticancer activity of certain herbs and spices on the cervical epithelial carcinoma (HeLa) cell line. Evid Based Complement Alternat Med 2012, 2012:1-11.

13. Sertel S, Eichhorn T, Plinkert P, Efferth T: Cytotoxicity of Thymus vulgaris essential oil towards human oral cavity squamous cell carcinoma. Anticancer Res 2011, 31:81-87.

14. Zu Y, Yu H, Liang L, Fu Y, Efferth T, Liu X, Wu N: Activities of ten essential oils towards Propionibacterium acnes and PC-3, A-549 and MCF-7 cancer cells. Molecules 2010, 15:3200-3210.

15. Jaafari A, Mouse H, Rakib E, Mbarek L, Tilaoui M, Benbakhta C, Boulli A, Abbad A, Zyad A: Chemical composition and antitumor activity of different wild varieties of Moroccan thyme. Rev Bras Farmacog 2007, 17:477-491.

16. Posadzki P, Watson L, Ernst E: Adverse effects of herbal medicines: an overview of systematic reviews. Clin Med 2013, 13:7-12.

17. Amir G, Karimi M: Cytotoxic activity of Thymus vulgaris, Achillea millefolium and Thuja orientalis on different growing cell lines. Med J Islam Repub Ira 2001, 15:149-154.

18. Al-Ali K, El-Beshbishy H, Alghaithy A, Abdallah H, El-Badry A, Abdel-Sattar E: In vitro antioxidant potential and antiprotozoal activity of methanolic 
extract of Mentha longifolia and Origanum syriacum. J Biol Sci 2013, 13:207-216.

19. Lakis Z, Mihele D, Nicorescu I, Vulturescu V, Udeanu D: The antimicrobial activity of Thymus vulgaris and Origanum syriacum essential oils on Staphylococcus aureus, Streptococcus pneumoniae and Candida albicans. Farmacia 2012, 60:857-865.

doi:10.1186/1756-0500-7-612

Cite this article as: Ayesh et al:: In vitro inhibition of human leukemia THP- 1 cells by Origanum syriacum L. and Thymus vulgaris L. extracts. BMC Research Notes 2014 7:612.

\section{Submit your next manuscript to BioMed Central and take full advantage of:}

- Convenient online submission

- Thorough peer review

- No space constraints or color figure charges

- Immediate publication on acceptance

- Inclusion in PubMed, CAS, Scopus and Google Scholar

- Research which is freely available for redistribution 